\title{
Amberlyst A-15: Reusable catalyst for the synthesis of 2,4,5-trisubstituted and 1,2,4,5-tetrasubstituted-1H-imidazoles under MW irradiation
}

\author{
SHIVAJI S PANDIT ${ }^{\mathrm{a}, *}$, SWAPNIL K BHALERAO ${ }^{\mathrm{a}}$, UDDHAV S AHER ${ }^{\mathrm{a}}$, GORAKSHANATH \\ L ADHAV $^{\mathrm{a}}$ and VIKRAM U PANDIT ${ }^{\mathrm{b}}$ \\ aPost Graduate and Research Centre, Department of Chemistry, Padmashri Vikhe Patil College Pravaranagar \\ (Loni Kd), Ahmednagar 413 713, India \\ ${ }^{b}$ Post Graduate and Research Centre, Department of Chemistry, Fergusson College Pune, Pune 411 004, India \\ e-mail: akankshapandit2002@yahoo.com
}

MS received 23 November 2010; revised 5 May 2011; accepted 11 May 2011

\begin{abstract}
One-pot multi-component condensation of benzyl, aldehydes, ammonium acetate and primary amines were used for synthesis of 2,4,5-trisubstituted and 1,2,4,5-tetrasubstituted- $H$-imidazole derivatives under MW radiation using amberlyst A-15 as a catalysts. This catalyst has several advantages (simple work-up, low cost and reusability).
\end{abstract}

Keywords. Amberlyst A-15; highly substituted imidazole; benzyl; aromatic aldehyde; amine; MW irradiation.

\section{Introduction}

Heterocyclic compounds with imidazole ring systems have many pharmaceutical activities and play important roles in biochemical processes. ${ }^{1}$ Highly substituted imidazole derivatives are also the key intermediates in the synthesis of many therapeutic agents. Omeprazole, Pimobendan, Losarton, Olmesartan, Eprosartan and Triphenagrel are some of the leading drugs in the market with diverse functionality. ${ }^{2}$ Triarylimidazoles are used in photography as photosensitive compound. ${ }^{3}$ In addition, they are of interest due to their herbicidal, ${ }^{4}$ analgesic, ${ }^{5}$ fungicidal, ${ }^{6}$ antiinflammatory ${ }^{7}$ and antithrombotic activities. ${ }^{8}$ There are numerous methods in the literature for the synthesis of highly substituted imidazoles: (a) condensation of 1,2-diones, aldehydes, primary amines and ammonia, ${ }^{9}$ (b) $N$-alkylation of trisubstituted imidazoles, ${ }^{10}$ (c) condensation of benzoin or benzoin acetate with aldehydes, primary amines and ammonia in the presence of copper acetate ${ }^{11}$ (d) cyclization of sulfonamides with mesoionic 1,3oxazolium-5-olates, ${ }^{12}$ (e) four component condensation of diones, aldehydes, primary amines and ammonium acetate in acetic acid under reflux conditions, ${ }^{13}$ (f) condensation of $\beta$-carbonyl $-N$-acyl- $N$-alkylamines with ammonium acetate in refluxing acetic $\operatorname{acid}^{14}$ and

*For correspondence (g) conversion of $N$-(2-oxo)amides with ammonium trifluoroacetate under neutral conditions. ${ }^{15}$

The original synthesis of imidazole utilized glyoxal, formaldehyde and ammonia that involve the formation of four $\mathrm{N}-\mathrm{C}$ bonds. ${ }^{16,17}$ Recently, combination of the supported reagents and microwave irradiations were used under solvent less conditions. ${ }^{18}$ Although, the reported methods are suffered by low yields, mixture of products, and lack of generality, harsh reaction conditions, excess of reagents. ${ }^{19}$ We report here simple and green approach for the synthesis of 2,4,5trisubstituted- $\mathrm{H}$-imidazole derivatives (scheme 1) by the condensation of benzyl, aldehydes, ammonium acetate and 1,2,4,5-tetrasubstituted- $1 \mathrm{H}$-imidazole derivatives (scheme 2) by the condensation of benzyl, aldehydes, ammonium acetate and primary amines using Amberlyst A-15. This catalyst is mild, water tolerant, recoverable, non-explosive, easy to handle, and reusable. In view of emerging importance of heterogeneous catalyst, we wish to explore the use of Amberlyst A- $15^{20}$ under MW irradiation.

\section{Results and discussion}

The condensation of 1,2-diketones(1), aldehydes (2) and ammonium acetate on exposure to microwave irradiation gave good to excellent yields of 2,4,5trisubstituted- $1 H$-imidazole derivatives (3a-3i) (table 1$)$ 


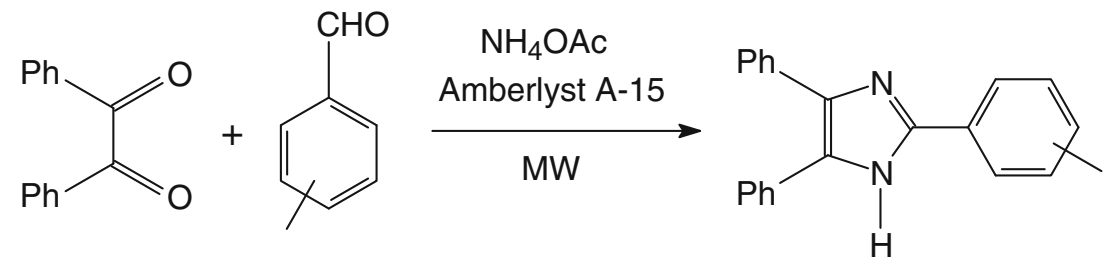

1

2

3

Scheme 1. Synthesis of 2,4,5-trisubstituted-1H-imidazole derivatives.

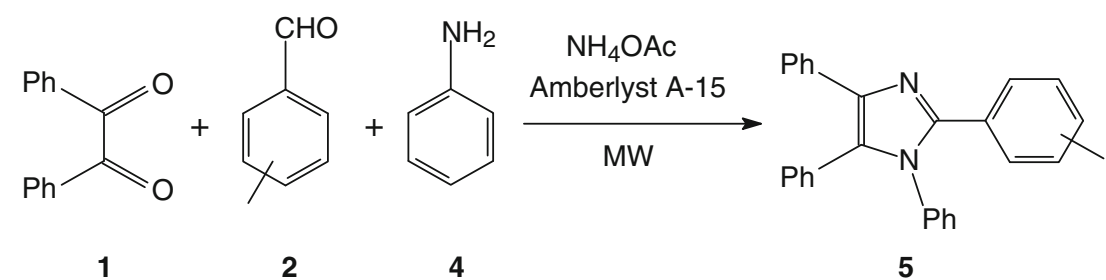

Scheme 2. Synthesis of 1,2,4,5-tetrasubstituted- $H$-imidazole derivatives.

Table 1. Condensation of benzyl, aldehyes and ammonium acetate using amberlyst A-15 under MW irradiation.

\begin{tabular}{|c|c|c|c|c|c|}
\hline Entry & Aldehyde 2 & Product 3 & Time (min.) & Yield $^{\mathrm{ab}}(\%)$ & $\operatorname{MP}\left({ }^{\circ} \mathrm{C}\right)^{\mathrm{c}}$ \\
\hline $\mathrm{a}$ & & $\dot{H}$ & 15 & 87 & $\begin{array}{c}271-272 \\
(274-276)^{19}\end{array}$ \\
\hline $\mathrm{b}$ & & $\dot{H}$ & 12 & 89 & $\begin{array}{c}229-231 \\
(234-236)^{8}\end{array}$ \\
\hline c & & & 12 & 88 & $\begin{array}{c}251-251 \\
(256-257)^{19}\end{array}$ \\
\hline $\mathrm{d}$ & & & 14 & 82 & $\begin{array}{c}252-253 \\
(256-257)^{20}\end{array}$ \\
\hline $\mathrm{e}$ & & & 13 & 83 & $\begin{array}{c}200-201 \\
(201-203)^{20}\end{array}$ \\
\hline
\end{tabular}


Table 1. Continued.

\begin{tabular}{|c|c|c|c|c|c|}
\hline Entry & Aldehyde 2 & Product 3 & Time (min.) & Yield $^{\mathrm{ab}}(\%)$ & $\mathrm{MP}\left({ }^{\circ} \mathrm{C}\right)^{\mathrm{c}}$ \\
\hline $\mathrm{f}$ & & -1 & 12 & 87 & $\begin{array}{c}253-254 \\
(256-258)^{20}\end{array}$ \\
\hline g & $\mathrm{Cl}$ & & 12 & 85 & $\begin{array}{c}179-181 \\
(183-184)^{20}\end{array}$ \\
\hline $\mathrm{h}$ & & & 12 & 92 & $240-242^{\mathrm{d}}$ \\
\hline $\mathrm{i}$ & & П & 12 & 89 & $\begin{array}{c}231-231 \\
(233-235)^{19}\end{array}$ \\
\hline
\end{tabular}

\footnotetext{
${ }^{\mathrm{a}}$ Isolated Products

${ }^{\mathrm{b}}$ All products are characterised by IR, ${ }^{1} \mathrm{HNMR}$, and compared with authentic samples

${ }^{\mathrm{c}}$ Literature data of known compounds

${ }^{\mathrm{d}}$ Spectroscopic data of new synthesized compounds
}

in presence of Amberlyst A-15. Similar methodology was applied for the synthesis of 1,2,4,5-tetrasubstituted$1 \mathrm{H}$-imidazole derivatives $(5 \mathrm{a}-5 \mathrm{~g})$ which were also obtained in good to excellent yields by the condensation of benzil (1), aldehydes (2), aromatic amines (4) and ammonium acetate (table 2) in presence of Amberlyst A-15 under solvent-free conditions. The synthesis of 2,4,5-trisubstituted and 1,2,4,5-tetrasubstituted-1 $\mathrm{H}$ imidazole derivatives using acetic acid for few hours is a well-established procedure. ${ }^{16}$ However, this method suffering by several drawbacks such as drastic reaction conditions, difficult to handle, longer reaction time, tedious work-up, low yields, etc. All such drawbacks were overcome in the present procedure as amberlyst A-15 is easy to handle, short reaction time, yields are good, simple work-up procedure. We have carried out aldehydes consisting electron withdrawing groups or electron donating groups at different positions but it did not show any remarkable difference in the yield of product and time of the reactions. All the reactions proceeded very efficiently and the results are summarized in table 1 . Similarly, we have studied the condensation of benzyl, aldehydes, ammonium acetate with primary aromatic amines. The neat reactions were also attempted under conventional heating, keeping similar reaction conditions. The direct heating of reactants without solvent took more time for completion of reactions and gave the products with low yields. In some reactions decomposition of reactants took place.

\subsection{Experimental}

A domestic microwave oven (Bajaj, ET-B at $2450 \mathrm{MHz}$, $100 \%$ power, $1300 \mathrm{~W}$ ) was used in all experiments. All melting points are uncorrected and were measured by open capillary method. IR spectra were run on JascoIR spectrometer. ${ }^{1} \mathrm{H}$ NMR spectra were recorded in $\mathrm{CDCl}_{3}$ with TMS as internal reference on Brucker AC-300 NMR spectrometer. 
Table 2. Condensation of benzyl, aldehydes, ammonium acetate and amine using Amberlyst A-15 under MW irradiation.

\begin{tabular}{|c|c|c|c|c|c|c|}
\hline Entry & Aldehyde 2 & Amine 4 & Product 3 & $\begin{array}{l}\text { Time } \\
\text { (min.) }\end{array}$ & $\begin{array}{c}\text { Yield }^{\mathrm{ab}} \\
(\%)\end{array}$ & $\begin{array}{l}\mathrm{MP} \\
\left({ }^{\circ} \mathrm{C}\right)^{\mathrm{c}}\end{array}$ \\
\hline
\end{tabular}

a<smiles>O=Cc1ccccc1</smiles><smiles>Nc1ccccc1</smiles><smiles>O=Cc1ccc(Cl)cc1</smiles><smiles>Nc1ccccc1</smiles><smiles>Nc1ccccc1</smiles>

c<smiles>O=Cc1ccc([N+](=O)[O-])cc1</smiles>

d<smiles>Cc1ccc(C=O)cc1</smiles><smiles>O=Cc1ccccc1</smiles><smiles>NCc1ccccc1</smiles><smiles>O=Cc1ccc(Cl)cc1</smiles><smiles>NCc1ccccc1</smiles>

$\mathrm{f}$

e<smiles>Cc1ccc(C=O)cc1</smiles><smiles>Nc1ccccc1</smiles><smiles>NCc1ccccc1</smiles><smiles>c1ccc(-c2nc(-c3ccccc3)n(-c3ccccc3)c2-c2ccccc2)cc1</smiles>

12<smiles>Clc1ccc(-c2nc(-c3ccccc3)c(-c3ccccc3)n2-c2ccccc2)cc1</smiles>

10

89<smiles>O=[N+]([O-])c1ccc(-c2nc(-c3ccccc3)c(-c3ccccc3)n2-c2ccccc2)cc1</smiles>

$12 \quad 84 \quad 167-170^{\mathrm{d}}$<smiles>Cc1ccc(-c2nc(-c3ccccc3)c(-c3ccccc3)n2-c2ccccc2)cc1</smiles>

$12 \quad 86$ 181-182 $(184-185)^{19}$<smiles>Cn1c(-c2ccccc2)nc(-c2ccccc2)c1-c1ccccc1</smiles>

$15 \quad 78 \quad 156-157$ $(158-160)^{19}$<smiles>Clc1ccc(-c2nc(-c3ccccc3)c(-c3ccccc3)n2Cc2ccccc2)cc1</smiles>

12<smiles>Cc1ccc(-c2nc(-c3ccccc3)c(-c3ccccc3)n2C)cc1</smiles>

${ }^{a}$ Isolated products

${ }^{\mathrm{b}}$ All products are characterised by IR, ${ }^{1} \mathrm{HNMR}$, and compared with authentic samples

${ }^{\mathrm{c}}$ Literature data of known compounds

${ }^{\mathrm{d}}$ Spectroscopic data of new synthesized compounds 


\subsection{Typical procedure}

Mixture of benzyl ( $5 \mathrm{mmol})$, 4-Nitro- benzaldehyde $(5 \mathrm{mmol})$ and $\mathrm{NH}_{4} \mathrm{OAc}(5 \mathrm{mmol})$, aromatic amine $(5 \mathrm{mmol})$ and Amberlyst A-15 (350 mg) into $50 \mathrm{ml}$ borosil beaker and irradiated with microwaves. The progress of reaction was monitored by TLC using pet.ether and ethyl acetate (9:1). After completion of the reaction the dichloromethane was added and the solid Amberlyst-A-15 was filtered and dried at $80^{\circ} \mathrm{C}$ and used for its reusability. The organic layer was extracted with $\mathrm{H}_{2} \mathrm{O}$ and dried by $\mathrm{Na}_{2} \mathrm{SO}_{4}$. The Organic layer was removed under reduced pressure. Further, the crude product was purified by column chromatography using pet. ether and ethyl acetate $(9: 1)$ on silica gel gave the product, 2-(4-Nitrophenyl)-4,5-diphenyl-1 $H$-imidazole and 2-(4-Nitrophenyl)-1,4,5-triphenyl-1 $H$-imidazole.

\subsection{Spectroscopic data}

2.3a 2(4-Nitrophenyl)-4, 5-diphenyl-1H-imidazole (3h): IR $\mathrm{KBr},\left(\mathrm{cm}^{-1}\right) 3400,1580,1515,1335 .{ }^{1} \mathrm{H}$ NMR $\left(\mathrm{CDCl}_{3}, 300 \mathrm{MHz}\right)$ : 7.1-7.6 (m, $\left.10 \mathrm{H}\right), 7.35(\mathrm{~d}$, $2 \mathrm{H}, \mathrm{J}=10 \mathrm{~Hz}, 7.85(\mathrm{~d}, 2 \mathrm{H}, \mathrm{J}=10 \mathrm{~Hz}), 8.9(\mathrm{bs}, 1 \mathrm{H})$.

$2.3 \mathrm{~b}$ 2-(4-Nitrophenyl)-1,4,5-triphenyl-1H-imidazole (5c): IR KBr, $\left(\mathrm{cm}^{-1}\right) 1605,1564,1481,1401 .{ }^{1} \mathrm{H}$ $\mathrm{NMR}\left(\mathrm{CDCl}_{3}, 300 \mathrm{MHz}\right): 7.17-7.84(\mathrm{~m}, 19 \mathrm{H})$.

\section{Conclusion}

In conclusion, we have developed a general and most efficient one-pot multi-component reaction for the synthesis of 2,4,5-trisubstituted- $1 \mathrm{H}$-imidazole and 1,2,4,5tetrasubstituted- $1 \mathrm{H}$-imidazole derivatives using heterogeneous and reusable catalysts Amberlyst A-15 under MW irradiation method which is environmentally friendly.

\section{Acknowledgements}

SSP thanks to University Grants Commission (UGC), New Delhi for financial assistance, wide letter no. f47-503/08(WRO), dated 15.01.2009 and thanks are also due to the Principal, Padmashri Vikhe Patil College Pravaranagar for providing laboratory facilities.

\section{References}

1. Sundberg R J and Martin R B 1974 Chem. Rev. 74471

2. (a) Bartlett M, Shaw M and Smith J W 1992 J. Med. Chem. Chim. Ther. 36 779; (b) Ghudamassi M, Barasent
J, Imbach J and Gayral P 1988 Eup. J. Med. Chem. 23 225; (c) Hazelton J, Iddon B, Redhouse A D and Susehitzky H 1995 Tetrahedron 51 5597; (d) Lee J C, Llaydon J T, McDowell P C, Gallagher T T, Kumar S, Green D, Mckulty D, Blumenthal M, Heys J R, Landvaller S W, Strikler J H, Mclaughlin M M, Siemen I R, Fisher S M, Livi G P, White J R, Adams J L and P R Young 1994 Nature 372 739; (e) Lindberg P, Nordberg P, Alminger T, Brandstorm A and Wallmark B 1986 J. Med. Chem. 29 1327; (f) Koike H, Konse T, Sada T, Ikeda T, Hyogo A, Hinman D, Saito H and Yanigasawa H 2003 Ann. Rep. Sankyo Res. Lab. 55 1; (f) Leister C, Wang Y, Zhao Z and Lindsley C W 2004 Org. Lett. 6 1453; (g) Mannhold R 1985 Drugs Future 10570

3. (a) Sensui H, Ichikawa J and Sato S 1987 Japan Kokkai Tokyo Koho JP, 6294 841: Chem Abstr. 107 187436q; (b) Satoru I 1989 Japan Kokkai Tokyo Koho JP 01117867 [89 117 867] Chem. Abst. 1989111 214482

4. Liebi R, Randte R, Mildenberger H, Bauer $\mathrm{K}$ and Bieringer H 1987 Chem. Abst. $1086018 \mathrm{~g}$

5. Wolkenberg S E, Wisnosk D D, Liester W B, Wang Y, Zhao Z and Lindsley C W 2004 Org. Lett. 61453

6. Pozherskii A F, Soldalenkov A T and Katritzky A R 1997 Heterocycles in Life, Society; (New York: Wiley) 179

7. Lombardino J G and Wiseman E H 1974 J. Med. Chem. 171182

8. Philips A P, White H L and Rosen S 1983 Eur. Pat. Appl. 1983, Eur. Pat. Appl. 58 890; Chem. Abst. 98 53894z

9. Stocek V and Schunack W 1974 Arch. Pharmaz 307922

10. Davidson D, Weiss M and Jelling M 1937 J. Org. Chem. 2319

11. Stocek V and Schunack W 1976 Arch. Pharmaz 309 421; (b) Lipshutz B H and Morey M C 1983 J. Org. Chem. 483745

12. Conssoni R, Croce P D, Ferraccioli R and Rosa $1991 \mathrm{~J}$. Chem. Res. (s) 188

13. (a) Schubert H and Stodolka J 1963 Prakt. Chem. 22 130; (b) Krieg B and Manccke G Z 1967 Naturforschung 222b 132

14. (a) Evans D A and Lundy K M 1992 J. Am. Chem. Soc. 114 1495; (b) Schneiders P, Heinze J and Baumgartel H 1973 Chem. Ber. 1062415

15. Claiborne C F, Liverton N J and Nguyen K T 1998 Tetrahedron Lett. 398939

16. Grimett M R In Comprehensive Heterocyclic Chemistry II; Katritzky A R, Rees C W and Scriven E F 1996 E. F. V. Eds. (New York: Pergamon) Vol. 3 P77

17. (a) Balalale S, Arabanian A and Hashtroudi M S 2000 Montash. Chem. 131 945; (b) Usyntinsky A Y and Khmelnitsky Y L 2000 Tetrahedron Lett. 415031

18. (a) Abrumovitch R A 1991 Org. Proc. Pre. Int. 23 683; (b) Mingos D M P and Bughurst D R 1991 Chem. Soc. Rev. 201; (c) Caddick S 1995 Tetrahedron 51 10403; (d) Struee C R and Trainer R W 1995 Aust. J. Chem. 48 1665; (e) Loupy A, Petit A, Hamclin J, Texler-Boulter P, Jacquault P and Mathe D 1998 Synthesis 1213; (f) Verma R S 1999 Green Chem. 1 43; (g) Verma R S 1999 Clean Products Process 1 132; (h) Nalage S V, Kalyankar M B, Patil V S, Bhosale S V, Dehmukh S U 
and Pawar R P 2010 The Open Catalysis Journal 3 58; (i) Zhao N, Wang Y L and Wang J Y 2005 J. Chinese Chemical Society 52 535; (j) Fantini M, Zulini V, Spotti M A and Rivara M 2010 J. Combinatorial Chem. 12(1) 181; (k) Pathan M, Paike V V, Pachmase P R, More S P, Ardhapure S S and Pawar R P 2006 Arkivoc (XV) 205; (1) Shelke K, Kakade G, Shingate B and Shingare M 2008 Rasayan J. Chem. 1(3) 489; (m) Bratulescu G 2009 Synthesis 14 2319; (n) Gribble G W and Joule J A 2009 Progress in Heterocyclic Chemistry, Elsevier, Page No. 232-233; (o) El. Ashry E S H, Rashed N, Awad L F, Ramadan E, Abdel-Maggeed S M and Rezki N 2007 Arkivoc (VII) 30; (p) El-Shaieb K M 2006 Heteroatom Chem. 17(5) 365

19. (a) Balalaie S, Hashem M M and Akhbari A 2003 Tetrahedron Lett. 44 (8) 1709; (b) Wassennan H H, Long Y O, Zhang R and Parr J 2002 Tetrahedron Lett. 43 3351; (c) Kamitori Y J 2001 Heterocycl. Chem. 38 773; (d) Kidwai M, Saxena S, Venkatraman R and Mohan R R 2002 J. C. S. Perkin Trans. I, 16 1845; (e) Kidwai M, and Mohan R R 2004 Canadian J. Chem. 82 427; (f) Kidwai M, Mothsra P, Bansal V and Goyal R 2006 Monatshefte Fur Chemie 137 1189; (g) Shaabani A, Rahmati A, Farhangi E and Badri Z 2007 Catalysis Communication 1149; (h) Balalie S and Arabanian A 2000 Green Chemistry 2 274; (i) Weiss M 1952 J. Org.
Chem. 74 5193; (j) Xu Y, Wan L F, Salchi H, Deng W and Gua O X 2004 Heterocycles 63 1613; (k) Adib M, Ansari S, Feizi S, Damavandi J A and Mirzaei P 2009 Synlett. 3263; (1) Zuliani V, Cocconcelli G, Fantini M, Ghiron C and Rivara M 2007 J. Org. Chem. 72 4551; (m) Siddiqui S A, Narkhede U C, Palimkar S S, Daniel T, Lahoti R J and Srinivasan K V 2005 Tetrahedron 61 3539; (n) Safari J, Khalili S D and Banitaba S H $2010 \mathrm{~J}$. Chem. Sci. 122(3) 347; (o) Arshia P, Azim A and Shaikh K A 2010 Research Journal of Pharmaceutical, Biological and Chemical Sciences 1(4) 943; (p) Baroniya S, Anwar Z, Sharma P K, Dudhe R and Kumar N 2010 1(3) 172; (q) Wang M, Gao J and Song Z 2010 Preparative Biochemistry and Biotechnology 40(4) 347

20. (a) Whiten D M and Sonnenberg B 1964 J. Org. Chem. 29 1926; (b) Schubert H and Stodalka H 1963 J. Pract. Chem. 22 130; (c) Venkat Narsaiah A, Reddy A R, Reddy B V S and Yadav J S 2011 The Open Catalysis Journal 4 43; (d) Pavan Kumar C N S S, Shrinivas C, Sadhu P S, Rao V J and Palaniappan S 2009 J. Heterocyclic Chem. 46(5) 997; (e) Liu Y H, Liu Q S and Zhang Z H 2008 J. Molecular Catalysis A: Chemical 296 42; (f) Tajbakhsh M, Heydari Akbar, Khalilzadeh M A Lakouraj M M, Zamenian B and Khaksar S 2007 Synlett. 15 2347; (g) Tajbakhsh M, Hosseinzadeh R and Lasemi Z 2004 Synlett. 4635 